\title{
Interannual variations in larval fish recruitment to estuarine epibenthic habitats*
}

\author{
Dennis M. Allen, D. Lynn Barker** \\ Belle W. Baruch Institute for Marine Biology and Coastal Research, University of South Carolina, Georgetown, \\ South Carolina 29442, USA
}

\begin{abstract}
The presence of early life stages of more than 45 fish species in epibenthic sled collections from North Inlet Estuary, South Carolina (USA) indicated that subtidal creek bottoms are important nursery habitats. Biweekly collections from 1981 to 1985 revealed 2 distinct periods of larval fish recruitment: summer, in which gobies Gobiosoma spp. and anchovies Anchoa spp. dominated; and winter, in which spot Leiostomus xanthurus and Atlantic croaker Micropogonias undulatus dominated. For every major taxon, date of arrival, duration of the recruitment period, and size distribution were similar among years. Arrival of early stage larvae was continuous within each annual period, but patterns of abundance were not consistent from year to year Large and irregular fluctuations in abundance between sampling dates accounted for the largest sources of variation in nested ANOVAs conducted for each of 8 major taxa, but these fluctuations were not explained by short-term changes in water temperature or salinity. However, during the extended period of low salinity in the winters of 1983 and 1984, winter taxa were significantly more abundant than in other years. Low salinity conditions represented extreme changes for an otherwise high salinity estuary, yet no notable differences in the taxonomic composition, ranks, or timing of arrivals were observed between the 4 winters sampled. Collections were made at sites representing the 2 dominant subtidal habitat types, and even though densities were consistently higher at an upestuary creek location than at one near the inlet, seasonal and annual patterns of abundance were very similar. Further, size distributions of larval fishes were very similar at both locations. These observations suggest that factors controlling larval fish recruitment and fluctuations in abundance were operating on a large spatial scale. Major ecosystem level disturbances such as extreme reductions in salinities during some winters did not appear to alter temporal patterns of larval fish recruitment as much as the magnitude of utilization of epibenthic habitats.
\end{abstract}

\section{INTRODUCTION}

The importance of estuaries as nursery areas for fishes is well documented (e.g. McHugh 1967, Herke 1971, Zijlstra 1972, Cain \& Dean 1976, Weinstein 1979), but more studies have focused on the utilization of estuarine habitats by juvenile than by early life stages. Spatial and temporal distributions of early life stages of fishes have been reported for sounds and bays (Pearcy \& Richards 1962, Herman 1963, Croker 1965, Dovel 1981, Dokken et al. 1984, Roper 1986, Bourne \& Govoni 1988), seagrass meadows (Carr \& Adams 1973, Olney \& Boehlert 1983), intertidal creeks (Shenker \& Dean

\footnotetext{
- Contribution no. 792 of the Belle W. Baruch Institute

- Present address: Dept of Zoology, NC State University, Raleigh, North Carolina 27695-7617, USA.
}

1979, Weinstein 1979, Bozeman \& Dean 1980), high marsh pools (Kneib 1984, Talbot \& Able 1984), and surf zones (Modde \& Ross 1981, Ruple 1984). All of these habitats appear to be important staging and growth areas, but there are considerable differences in the taxonomic and life stage composition of fishes among habitats, even within the same estuary. Geographic variations in the kinds of fishes utilizing a specific habitat type seem less pronounced than the temporal dynamics of occupation. For instance, gobies, anchovies, herrings, and drums dominate the estuarine ichthyoplankton of South Africa (Beckley 1986), Australia (Jenkins 1986), New Zealand (Roper 1986), Gulf of Mexico (Dokken et al. 1984, Ruple 1984), and Chesapeake Bay, USA (Dovel 1981, Olney 1983), but differences in the seasonal cycles are large. Spawning and larval recruitment times are closely related to 
water temperature and photoperiod (Cushing 1975 , Bye 1984) and to seasonal production cycles of zooplankton and phytoplankton (Royce 1972, Sherman et al. 1984). For North American species which occur throughout wide geographic ranges, arrival times are earlier and recruitment periods are longer toward the southern ends of their ranges (Dahlberg \& Conyers 1973, Chao \& Musick 1977. Powles \& Stender 1978, Colton et al. 1979). Nevertheless, the temporal patterns of utilization of specific habitats at any location seem to vary little among years.

Even though the regularity with which certain larval fishes arrive at estuarine nursery habitats is widely recognized, few studies have examined interannual variations and factors which influence fluctuations in recruitment dynamics. Most estuarine ichthyoplankton studies have been based on time series of about $1 \mathrm{yr}$, but Able (1978) and Holt \& Strawn (1983) compared patterns of larval fish abundance over periods of about 3 yr. Long-term data are essential to document and interpret interannual variations in the timing and magnitude of larval fish recruitment. The present study is based on biweekly collections over a 4 yr period. Abundance and length data of larval fishes collected in the epibenthic zone of high salinity tidal creeks were used to identify recruitment patterns, and relationships to environmental parameters were examined. In this study, the term recruitment refers to the arrival of larval and postlarval stages of fishes to estuarine epibenthic habitats as well as the subsequent utilization of these areas by early life stages.

\section{STUDY AREA}

Collections were made from tidal creeks in the North Inlet Estuary, Georgetown County, South Carolina (Fig. 1). The $32 \mathrm{~km}^{2}$ Spartina alterniflora marsh estuary is strongly influenced by semi-diurnal tides which have a mean range of $1.4 \mathrm{~m}$, create peak current velocities of up to $2 \mathrm{~m} \mathrm{~s}^{-1}$, and result in more than $40 \%$ of the water in the estuary at high tide being flushed to the ocean on an average ebb tide (Kjerfve et al. 1982). Salinities in this well-mixed system are typically 32 to $35 \mathrm{ppt}$, but during winter periods when freshwater inflow from the surrounding forest or Winyah Bay Estuary is high, salinities in the tidal creeks may be lowered for weeks or months (Fig. 2).

Both sampling sites were at Town Creek (Fig. 1). Stn DD had a rippled sand bottom superimposed on a changeable ridge and swale relief which is typical of areas influenced by strong tidal currents. Depth was about $4 \mathrm{~m}$ at the time of sampling. Sessile epibenthic assemblages were not well developed at Stn DD, but, at $\operatorname{Stn} \mathrm{BB}$, an irregular muddy-sand bottom with a large shell component supported growths of algae, sponges, bryozoans, octocorals, and hydroids. Current velocities were slower and bottom topography was more stable at $\mathrm{BB}$ where the depth was about $3 \mathrm{~m}$ at the time of sampling.

\section{METHODS AND MATERIALS}

Samples were collected with an epibenthic sled designed to collect small motile animals within $30 \mathrm{~cm}$ of the creek bottom. The apparatus consisted of a rectangular steel frame $(51 \times 30 \mathrm{~cm})$ which oriented the mouth of a $365 \mu \mathrm{m}$ mesh Nitex plankton net perpendicular to the bottom. This frame was mounted on a horizontal chassis with skis which allowed the sampler to be towed across the bottom without digging into the sediment. The sled was towed from a small outboard boat in the direction on the tide. Water volume filtered was estimated with a General Oceanics flowmeter (model \# 2040) mounted inside of the net mouth. Samples were collected every 12 to 15 d from January 1981 through January 1985 . Three sequential tows were made along $100 \mathrm{~m}$ paths at each location. Collections were made about $2 \mathrm{~h}$ prior to the mid-day low tide. Bottom water temperature and salinity were measured in the tow path before the first collection.

A total of 594 samples were collected, preserved with Rose Bengal $\left(0.5 \mathrm{~g} \mathrm{l}^{-1}\right)$ stained buffered formalin, and returned to the laboratory for processing. Entire samples were usually analyzed, but when volumes exceeded about $100 \mathrm{ml}$ a cylindrical splitter was used to obtain a subsample containing no less than $12.5 \%$ of the original volume. Abundance estimates are mean densities (no. per $\mathrm{m}^{3} \pm 1$ standard error) based on 3 replicates from each combination of date and station.

Notochord length (NL) or standard length (SL) was measured for up to 100 individuals of each species from each date and location. Unidentified fish larvae (Table 1) were mostly unpigmented yolk sac larvae, but some damaged specimens were included.

Abundance data were transformed to $\log _{10}(x+1)$ to normalize the distribution and to decorrelate means and variances. Statistical analyses were based on the General Linear Model and nested ANOVA procedures of SAS (SAS 1982). ANOVAs were performed on transformed data utilizing a complete block design (Sokal \& Rohlf 1981). Each source of variation was considered to be nested within preceding sources of variation (e.g. total variation due to date is actually variation due to differences among dates within years nested within sites). Comparisons of abundance between stations and years were with Tukey's Studentized Range Test (Mize \& Schultz 1985). 


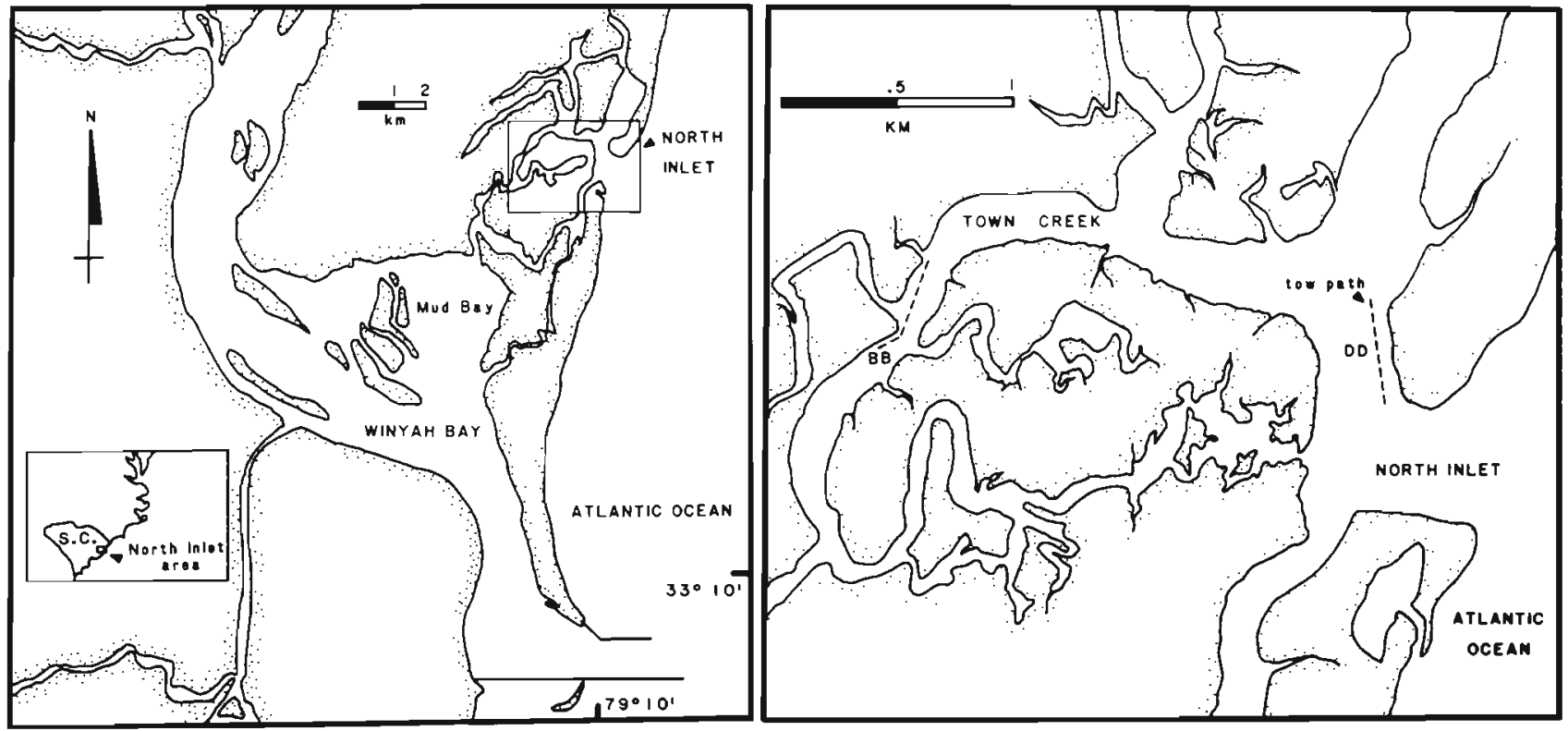

Fig. 1. Maps showing the relationship between North Inlet and Winyah Bay Estuaries and the location of tidal creek collection sites, Stns BB and DD, in the North Inlet Estuary
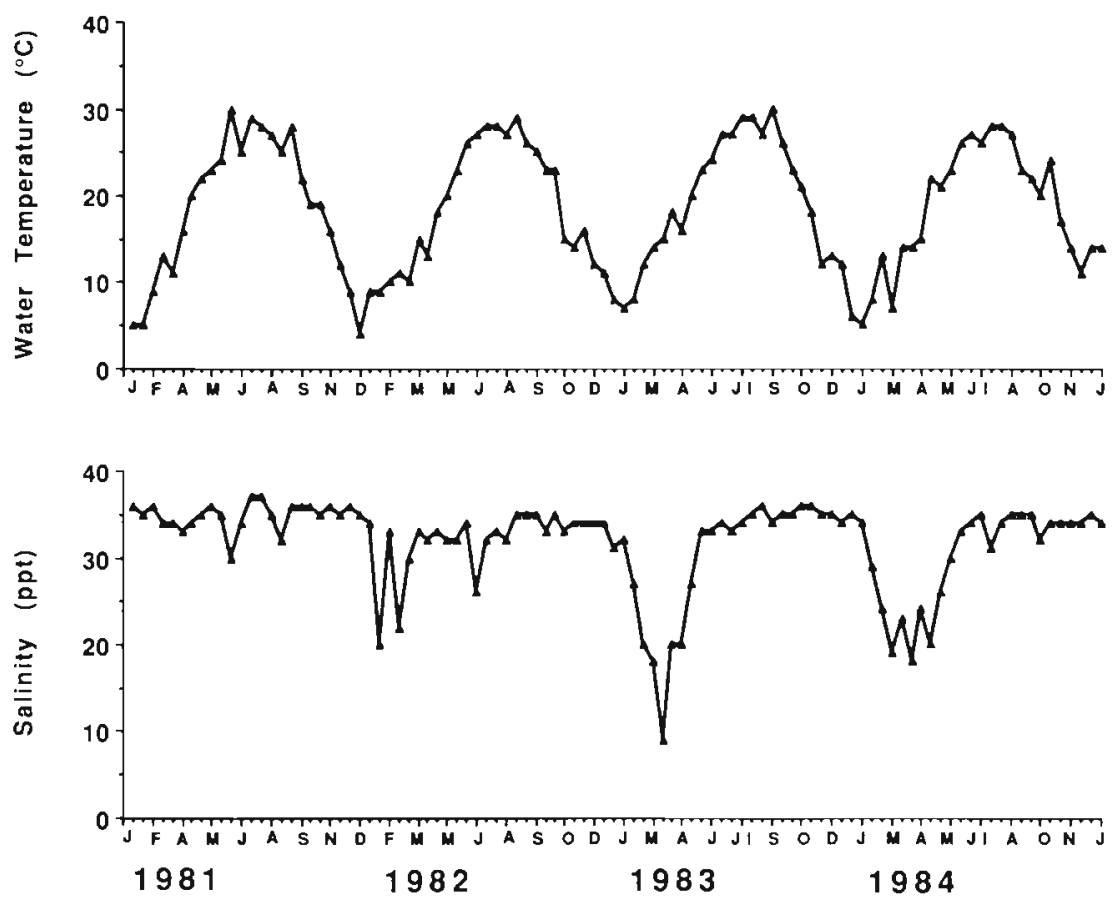

Fig. 2. Bottom water temperature and salinity values at Stn BB based on biweekly measurements between January 1981 and 1985

\section{RESULTS}

Larvae were present year-round (97 of 99 sampling dates from 1981 to 1985), but distinct seasonal patterns of abundance were observed each year (Fig. 3). The annual recruitment cycle was characterized by a winter period (October through March) and a summer period (April through September) when larvae were much more abundant (Fig. 3). Periods of low total catch densities in spring and fall separated distinct summer and winter assemblages. Species richness was highest from April through September when larvae representing 20 of the 23 families were collected. Larvae belonging to the remaining 3 families (Ophichthidae, Clupeidae, and Sparidae) only occurred during the winter (Table 1). No genus was represented by larvae 
Table 1. List of taxa, location of reproduction (Loc.), total number of individuals collected (Total), percent of total catch (\%), number of cruises out of 99 on which taxa was collected (Freq.), period (Period) and season (Seas.) of occurrence, water temperature range (Temp.), and length range (Size, $\mathrm{mm}$ ) of larval and juvenile fishes in epibenthic sled collections at North Inlet Estuary, South Carolina, USA. Data represent combined catches from 2 locations sampled biweekly from 20 January, 1981 to 21 January 1985. Symbols for locations of spawning: E, estuary; SC, shallow coastal; DC, deep coastal. Symbols for seasons of occurrence: $S$, summer; $W$, winter. Note that although the presence of a few small juvenile fishes in the collections resulted in large size ranges for some taxa, the majority of individuals of all taxa were close to the smallest size indicated

\begin{tabular}{|c|c|c|c|c|c|c|c|c|}
\hline Family species & Loc. & Total & $\%$ & Freq. & Period & Seas. & Temp. $\left({ }^{\circ} \mathrm{C}\right)$ & Size $(\mathrm{mm})$ \\
\hline \multicolumn{9}{|l|}{ Ophichthidae, snake eels } \\
\hline Myrophis punctatus & $\mathrm{DC}$ & 1026 & 1.04 & 28 & Dec-Mar & W & $4.2-16.1$ & $48.5-80.0$ \\
\hline \multicolumn{9}{|l|}{ Clupeidae, herrings } \\
\hline Brevoortia spp. & $\mathrm{DC}$ & 17 & 0.02 & 7 & Feb-Apr & W & $7.2-14.7$ & $20.3-27.2$ \\
\hline \multicolumn{9}{|l|}{ Engraulidae, anchovies } \\
\hline Anchoa spp. ${ }^{2}$ & $\mathrm{SC} / \mathrm{E}$ & 4703 & 4.76 & 46 & Apr-Nov & $s$ & $8.0-30.0$ & $2.3-20.0$ \\
\hline \multicolumn{9}{|l|}{ Batrachoididae, toadfishes } \\
\hline Opsanus tau & $\mathrm{E}$ & 16 & 0.02 & 9 & Apr-Aug & $\mathrm{S}$ & $18.2-30.0$ & $18.6-29.5$ \\
\hline \multicolumn{9}{|l|}{ Gobiesocidae, clingfishes } \\
\hline Gobiesox strumous & $E$ & 135 & 0.14 & 17 & $\mathrm{Apr}-\mathrm{Oct}$ & $\mathrm{S}$ & $18.2-30.0$ & $1.9-11.7$ \\
\hline Atherinidae, silversides & $E$ & 15 & 0.02 & 7 & Apr-Aug & $\mathrm{S}$ & $14.0-30.0$ & $2.9-12.3$ \\
\hline \multicolumn{9}{|l|}{ Syngnathidae, pipefishes } \\
\hline Synagnathus spp. & $\mathrm{SC} / \mathrm{E}$ & 183 & 0.20 & 39 & Feb-Oct & $\mathrm{S}$ & $8.2-30.0$ & $9.0-75.2$ \\
\hline \multicolumn{9}{|l|}{ Serranidae, sea basses } \\
\hline Mycteroperca microlepis & $\mathrm{DC}$ & 1 & $\cdot$ & 1 & Apr & $\mathrm{S}$ & 19.6 & 16.3 \\
\hline \multicolumn{9}{|l|}{ Carangidae, jacks } \\
\hline Chloroscombrus chrysurus & $\mathrm{SC}$ & 3 & $\cdot$ & 2 & Sept & $\mathrm{S}$ & $23.2-27.8$ & $7.1-7.7$ \\
\hline \multicolumn{9}{|l|}{ Haemulidae, grunts } \\
\hline Orthopristis chrysoptera & $\mathrm{SC} ?$ & 29 & 0.03 & 8 & Apr-Jun & $\mathrm{S}$ & $14.8-26.1$ & $9.5-14.9$ \\
\hline \multicolumn{9}{|l|}{ Sparidae, porgies } \\
\hline Lagodon rhomboides & $\mathrm{DC}$ & 632 & 0.64 & 21 & Dec-Mar & W & $4.2-14.2$ & $11.5-17.4$ \\
\hline \multicolumn{9}{|l|}{ Sciaenidae, drums } \\
\hline Bairdiella chrysoura & $\mathrm{E} / \mathrm{SC}$ & 573 & 0.58 & 17 & May-Aug & S & $20.6-27.1$ & $2.3-6.3$ \\
\hline Cynoscion nebulosus & $\mathrm{E} / \mathrm{SC}$ & 102 & 0.10 & 12 & Jun-Sep & $\mathrm{S}$ & $23.6-30.0$ & $1.7-5.1$ \\
\hline Cynoscion regalis & $\mathrm{E} / \mathrm{SC}$ & 741 & 0.75 & 25 & Apr-Sep & $\mathrm{S}$ & $20.1-30.0$ & $2.9-8.5$ \\
\hline Leiostomus xanthurus & $\mathrm{DC}$ & 4418 & 4.47 & 35 & Dec-Nay & W & $4.5-22.5$ & $9.5-38.2$ \\
\hline Menticirrhus spp ${ }^{c}$ & $\mathrm{E} / \mathrm{SC}$ & 18 & 0.02 & 8 & May-Oct & $\mathrm{S}$ & $20.6-30.0$ & $2.6-5.8$ \\
\hline Micropogonias undulatus & $\mathrm{DC}$ & 1260 & 1.27 & 42 & Oct-Apr & W & $4.2-24.0$ & $5.4-24.8$ \\
\hline Pogonias cromis & $\mathrm{E} / \mathrm{SC}$ & 37 & 0.04 & 5 & May-Aug & $\mathrm{S}$ & $20.1-29.4$ & $3.4-4.6$ \\
\hline Sciaenops ocellatus & $\mathrm{E} / \mathrm{SC}$ & 13 & $\cdot$ & 4 & Jul-Sep & $\mathrm{S}$ & $25.3-28.0$ & $4.9-7.7$ \\
\hline Stellifer lanceolatus & $\mathrm{E}$ & 1 & $\cdot$ & 1 & Aug & $\mathrm{S}$ & 28.5 & 8.5 \\
\hline Unidentified sciaenid larvae & & 41 & 0.04 & 11 & Apr-Sep & $\mathrm{S}$ & $21.5-30.0$ & $2.0-6.9$ \\
\hline \multicolumn{9}{|l|}{ Ephipidae, spadefishes } \\
\hline Chaetodipterus faber & $\mathrm{SC}$ & 6 & $\cdot$ & 3 & Jul-Sep & S & $25.3-28.0$ & $4.3-8.3$ \\
\hline \multicolumn{9}{|l|}{ Uranoscopidae, stargazers } \\
\hline Astroscopus sp. & $\mathrm{SC}$ ? & 1 & $\cdot$ & 1 & Oct & $\mathrm{S}$ & 15.2 & 24.0 \\
\hline Blenniidae, combtooth blennies ${ }^{d}$ & E & 959 & 0.97 & 44 & Apr-Nov & $\mathrm{S}$ & $18.2-30.0$ & $1.4-17.8$ \\
\hline \multicolumn{9}{|l|}{ Eleotridae, sleepers } \\
\hline Dormitator maculatus & $E$ & 1 & $\cdot$ & 1 & May & $\mathrm{S}$ & 27.5 & 7.4 \\
\hline \multicolumn{9}{|l|}{ Gobiidae, gobies } \\
\hline Gobionellus spp. & $\mathrm{E} / \mathrm{SC} ?$ & 59 & 0.06 & 12 & Dec-Apr & W & $4.2-27.0$ & $9.0-15.4$ \\
\hline Gobiosoma spp. & $E$ & 82677 & 83.60 & 56 & Mar-Oct & s & $13.2-30.0$ & $1.8-18.4$ \\
\hline Microgobius spp. & $\mathrm{E} / \mathrm{SC} ?$ & 196 & 0.20 & 23 & Apr-Oct & $s$ & $18.2-30.0$ & $4.2-11.0$ \\
\hline \multicolumn{9}{|l|}{ Triglidae, searobins } \\
\hline Prionotus spp. & $\mathrm{SC}$ & 14 & $\cdot$ & 9 & Mar-Sept & $s$ & $10.4-30.0$ & $11.7-30.2$ \\
\hline \multicolumn{9}{|l|}{ Bothidae, lefteye flounders } \\
\hline Citharichthys sp. ${ }^{1}$ & $\mathrm{SC} ?$ & 18 & 0.02 & 6 & Mar-May & W & $10.3-28.9$ & $9.4-27.3$ \\
\hline Etropus sp! & $\mathrm{SC}$ & 3 & $\cdot$ & 5 & May-Sep & $\mathrm{S}$ & $10.4-28.9$ & $10.3-28.7$ \\
\hline Paralichthys spp. ${ }^{k}$ & $\mathrm{DC}$ & 89 & 0.09 & 11 & Dec-Apr & w & $4.2-22.3$ & $8.1-29.5$ \\
\hline \multicolumn{9}{|l|}{ Soleidae, soles } \\
\hline Trinectes maculatus & $E$ & 220 & 0.22 & 21. & May-Sep & $\mathrm{S}$ & $22.5-30.0$ & $1.4-4.9$ \\
\hline
\end{tabular}


Table 1 (continued)

\begin{tabular}{|c|c|c|c|c|c|c|c|c|}
\hline Family species & Loc. & Total & $\%$ & Freq. & Period & Seas. & Temp. $\left({ }^{\circ} \mathrm{C}\right)$ & Size $(\mathrm{mm})$ \\
\hline \multicolumn{9}{|l|}{ Cynoglossidae, tonguefishes } \\
\hline Symphurus plagiusa & $\mathrm{SC}$ & 36 & 0.04 & 15 & Mar-Dec & $S$ & $10.4-30.0$ & $8.8-28.0$ \\
\hline \multicolumn{9}{|l|}{ Balistidae, leatherjackets } \\
\hline Monacanthus hispidus & $\mathrm{DC}$ & 11 & • & 6 & May-Aug & $\mathrm{S}$ & $11.8-29.3$ & $14.0-24.0$ \\
\hline \multicolumn{9}{|l|}{ Tetraodontidae, puffers } \\
\hline Sphoeroides maculatus & DC & 3 & · & 2 & May & $\mathrm{S}$ & 22.5 & $9.9-10.8$ \\
\hline \multirow[t]{2}{*}{ Unidentified larvae } & & 614 & 0.62 & 23 & Apr-Oct & $S$ & $11.8-30.0$ & $1.4-5.1$ \\
\hline & & 98871 & 100.00 & & & & & \\
\hline \\
\hline \multicolumn{9}{|c|}{ Anchoa hepsetus and A. mitchilli; specimens $>20 \mathrm{~mm}$ excluded $(\mathrm{n}=1)$} \\
\hline \multirow{2}{*}{\multicolumn{9}{|c|}{$\begin{array}{l}\text { - Syngnathus floridae, S. fuscus and S. louisianae; specimens }>80 \mathrm{~mm} \text { SL excluded }(\mathrm{n}=17) \\
\text { cMenticirrhus littoralis, and } M \text { saxatilis }\end{array}$}} \\
\hline & & & & & & & & \\
\hline \multicolumn{9}{|c|}{$\begin{array}{l}\text { 'Chasmodes bosquianus, Hypleurochilus geminatus, Hypsoblennius hentzi, Hypsoblennius ionthas; specimens }>20 \mathrm{~mm} \\
\text { excluded }(\mathrm{n}=4)\end{array}$} \\
\hline \multicolumn{9}{|c|}{ 'Gobionellus boleosoma and G. hastatus } \\
\hline \multicolumn{9}{|c|}{ f Gobiosoma bosci and Gobiosoma ginsburgi; specimens $>20 \mathrm{~mm}$ excluded $(\mathrm{n}=2$ ) } \\
\hline \multicolumn{9}{|c|}{ g Microgobius gulosus and $M$. thalassinus } \\
\hline \multicolumn{9}{|c|}{ h Prionotus evolans, $P$. scitulus and $P$. tribulus } \\
\hline \multicolumn{9}{|l|}{${ }^{1}$ cf. Citharichthys spilopterus } \\
\hline \multicolumn{9}{|c|}{${ }^{1}$ cf. Etropus crossotus; specimens $>30 \mathrm{~mm}$ excluded $(\mathrm{n}=2)$} \\
\hline \multicolumn{9}{|c|}{${ }^{k}$ Paralichthys dentatus and $P$. lethostigma } \\
\hline 1 Specimens $>30 \mathrm{~mm}$ excluded & & & & & & & & \\
\hline
\end{tabular}
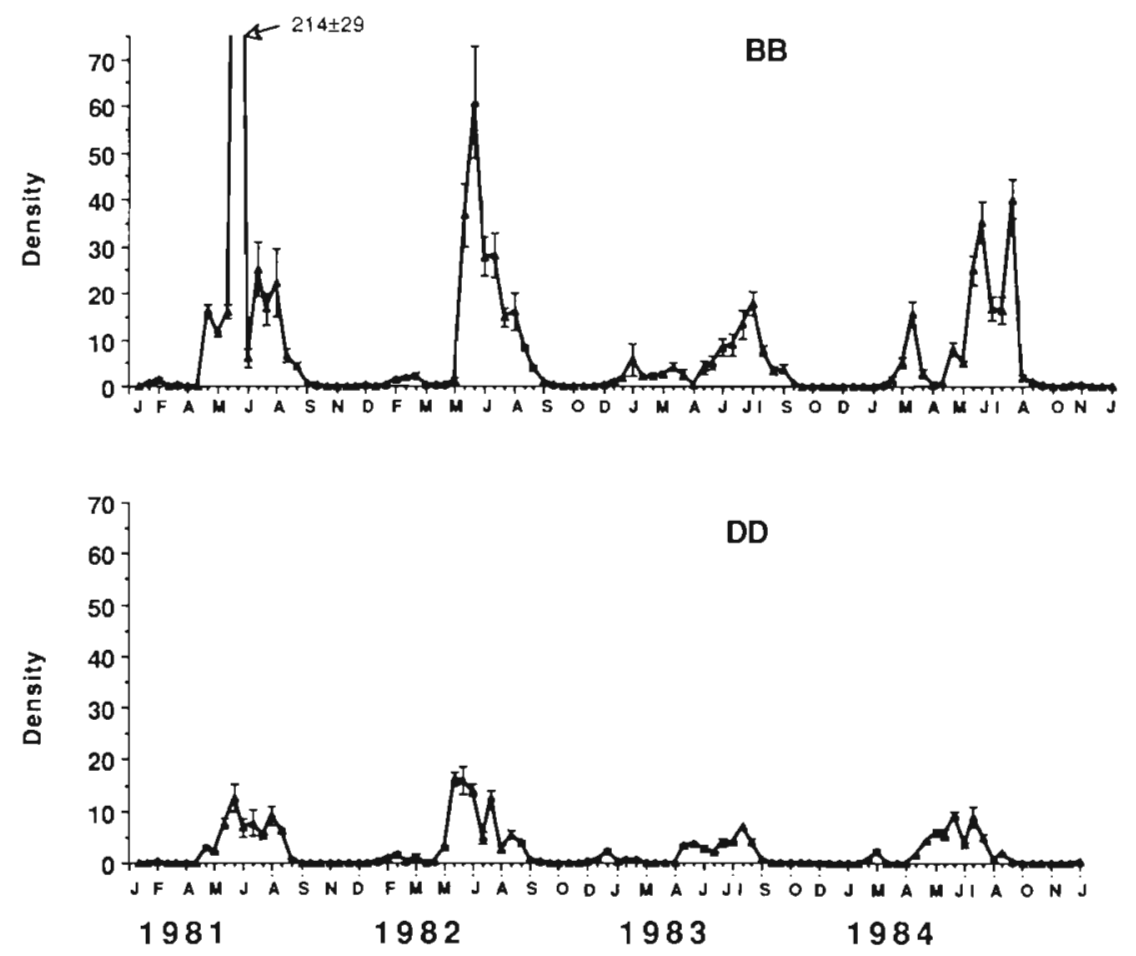

Fig. 3. Total larval fish densities (number $\mathrm{m}^{-3}$ ) in biweekly epibenthic sled collections at Stns BB and DD. Values are means of 3 replicates. Vertical bars indicate 1 standard error 
throughout the year. Although 45 species of fishes occurred in epibenthic sled collections, 3 genera (Gobiosoma, Anchoa, and Leiostomus) accounted for more than $93 \%$ of the total number of larvae collected.

Summer collections were dominated by gobies Gobiosoma spp. and anchovies Anchoa spp. which comprised about $84 \%$ and $5 \%$ of the total catch, respectively (Table 1). Most of the goby larvae were naked gobies (G. bosci) (D. Ruple pers. comm.) and most anchovies were bay anchovies A. mitchilli. Both were present in almost every collection during the 4 summers. Blennies (Blenniidae), weakfish Cynoscion regalis, and silver perch Bairdiella chrysoura were also important constituents of the summer larval fish assemblage. In winter, spot Leiostomus xanthurus and Atlantic croaker Micropogonias undulatus larvae accounted for about $58 \%$ and $5 \%$ of the total catch, respectively. Pinfish Lagodon rhomboides and speckled worm eel Myrophis punctatus were also common winter larvae (Table 1).

Within each of the seasonal recruitment periods, specific arrival times (dates of first occurrence) were identified for common taxa, and interannual variations were small (Table 2). For example, Gobiosoma spp., Anchoa spp., and Blenniidae were first collected during the same 2 to 3 wk period every April-May (Table 2). Each year silver perch and weakfish arrived in late May. Atlantic croakers were the earliest of the winter larvae to arrive each year, while spot, pinfish, and worm eels were first collected during the same $3 \mathrm{wk}$ period every December-January. Consistent relationships were not observed between interannual variations in arrival times and corresponding water temperatures and salinities (Figs. 2, 3, 4, and 5). Interannual differences in water temperature on the dates of first occurrence were often large (up to $12^{\circ} \mathrm{C}$ ).

The durations of larval recruitment periods within taxa did not vary much among years (Table 2). Continuous recruitment during well-defined, 5 to $7 \mathrm{mo}$ periods occurred for the most common taxa (Tables 1 and 2). The dates on which larvae of major taxa were last collected were as regular as dates of first collection.

In general, summer larvae were smaller $(<5 \mathrm{~mm})$ than winter larvae $(>10 \mathrm{~mm})$. Among taxa, length ranges varied considerably, but within taxa, length distributions were similar each year (Table 1; Figs. 4 and 5). Smallest mean lengths usually occurred near the beginning and largest individuals were usually collected near the end of each period; however, small individuals were present throughout the recruitment periods of most common taxa.

Abundance patterns were highly variable within the recruitment periods of all major taxa (Figs. 4 and 5). Variability associated with cruise dates accounted for the largest (52 to $87 \%$ ) source of variability in nested ANOVAs for each of the 6 most abundant taxa (Table 3). The shapes of abundance curves and the timing and magnitude of peak densities differed as much within taxa as between taxa during the 4 yr study (Figs. 4 and 5). There were no consistent relationships between short-term fluctuations in abundance, water temperature, and salinity (Figs. 2, 4 and 5).

In the nested ANOVAs, interannual variations in abundance usually accounted for less than $10 \%$ of the total variability in the dataset (Table 3). Comparisons of annual mean abundance within taxa indicated that differences were usually not significant (Table 4). Major winter taxa, especially spot, Atlantic croaker, and pinfish, were most abundant in 1983 and 1984 (Table 4; Fig. 5) when salinities were lowest (Fig. 2). Gobies, anchovies, and blennies were least abundant following the wet winters of 1983 and 1984 (Table 4; Fig. 4).

The total larval fish catch was larger at creek site BB

Table 2. Comparisons of the duration of periods of recruitment to epibenthic habitats (Wks = number of weeks present) and dates of first collection (Date) among years for the 8 most abundant larval fish taxa

\begin{tabular}{|c|c|c|c|c|c|c|c|c|}
\hline \multirow[t]{2}{*}{ Summer fishes } & \multicolumn{2}{|c|}{1981} & \multicolumn{2}{|c|}{1982} & \multicolumn{2}{|c|}{1983} & \multicolumn{2}{|c|}{1984} \\
\hline & Wks & Date & Wks & Date & Wks & Date & Wks & Date \\
\hline Gobiosoma spp. & 26 & Apr 17 & 26 & Apr 20 & 26 & Apr 26 & 26 & Apr 12 \\
\hline Anchoa spp. & 20 & Apr 30 & 26 & Apr 7 & 20 & May 10 & 20 & Apr 30 \\
\hline Bairdiella chrysoura & 8 & Jun 1 & 8 & May 19 & 8 & May 24 & 6 & Nay 11 \\
\hline Blenniidae & 24 & Apr 30 & 24 & Apr 20 & 16 & May 10 & 24 & Apr 30 \\
\hline \multirow[t]{2}{*}{ Winter fishes } & \multicolumn{2}{|c|}{$1981 / 82$} & \multicolumn{2}{|c|}{$1982 / 83$} & \multicolumn{2}{|c|}{$1983 / 84$} & \multicolumn{2}{|c|}{$1.984 / 85$} \\
\hline & Wks & Date & Wks & Date & Wks & Date & Wks & Date \\
\hline Leiostomus xanthurus & 18 & Dec 21 & 22 & Dec 15 & 22 & $\operatorname{Jan} 3$ & - & $>\operatorname{Jan} 4$ \\
\hline Micropogonias undulatus & 22 & Nov 24 & 28 & Oct 29 & 24 & Nov 18 & - & Oct 5 \\
\hline Lagodon rhomboides & 14 & $\operatorname{Dec} 9$ & 12 & $\operatorname{Jan} 13$ & 12 & $\operatorname{Jan} 3$ & - & $>\operatorname{Jan} 4$ \\
\hline Myrophis punctatus & 14 & $\operatorname{Dec} 9$ & 18 & Nov 29 & 14 & Dec 1.9 & - & $\operatorname{Dec} 6$ \\
\hline
\end{tabular}



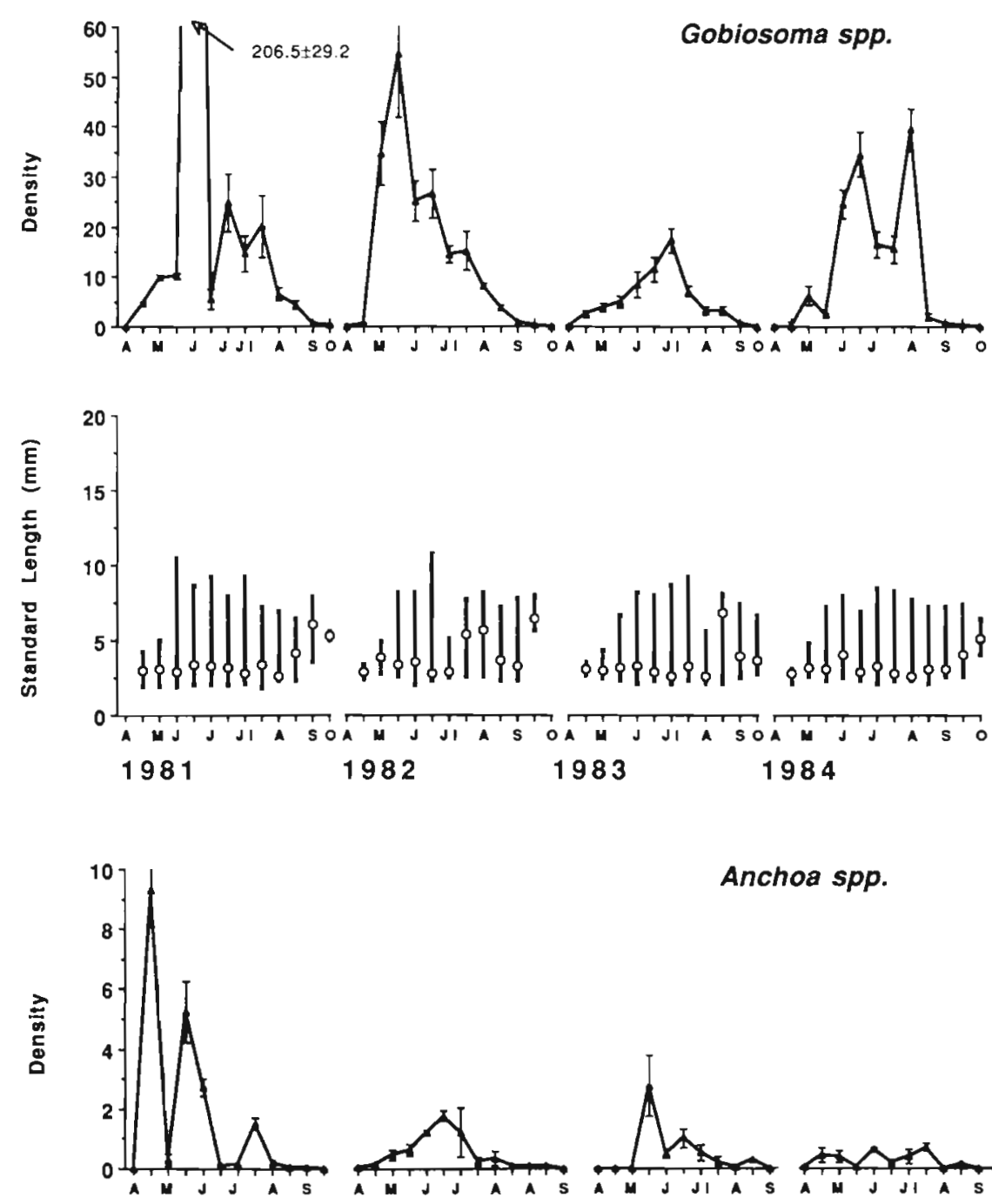

Anchoa spp.

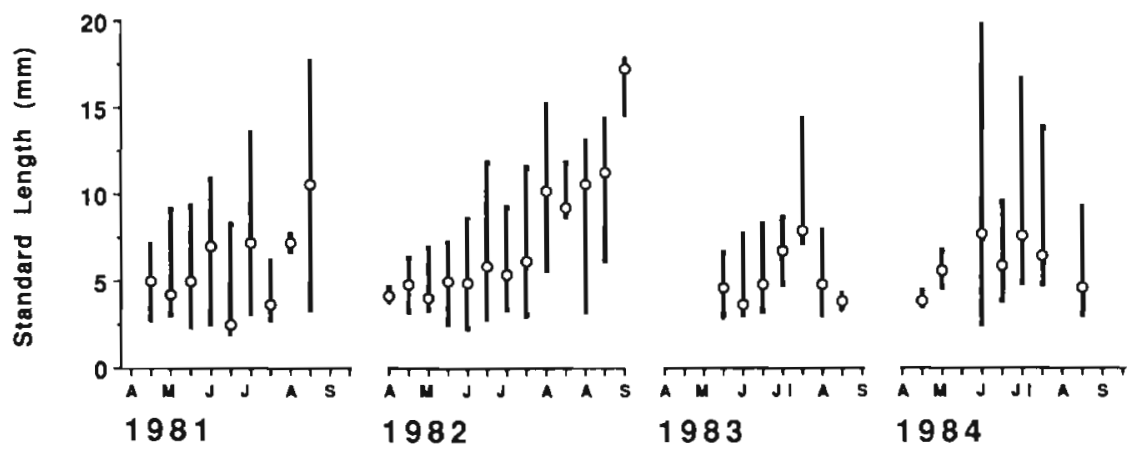

Fig. 4. Gobiosoma spp. and Anchoa spp. Densities (mean \pm 1 standard error) expressed as number $\mathrm{m}^{-3}$ of gobies and anchovies in biweekly epibenthic sled collections at Stn BB and corresponding length distributions for those dates on which at least 10 individuals were collected. On length distribution plots, open circles indicate median length and solid lines terminate at the minimum and maximum length for that date 

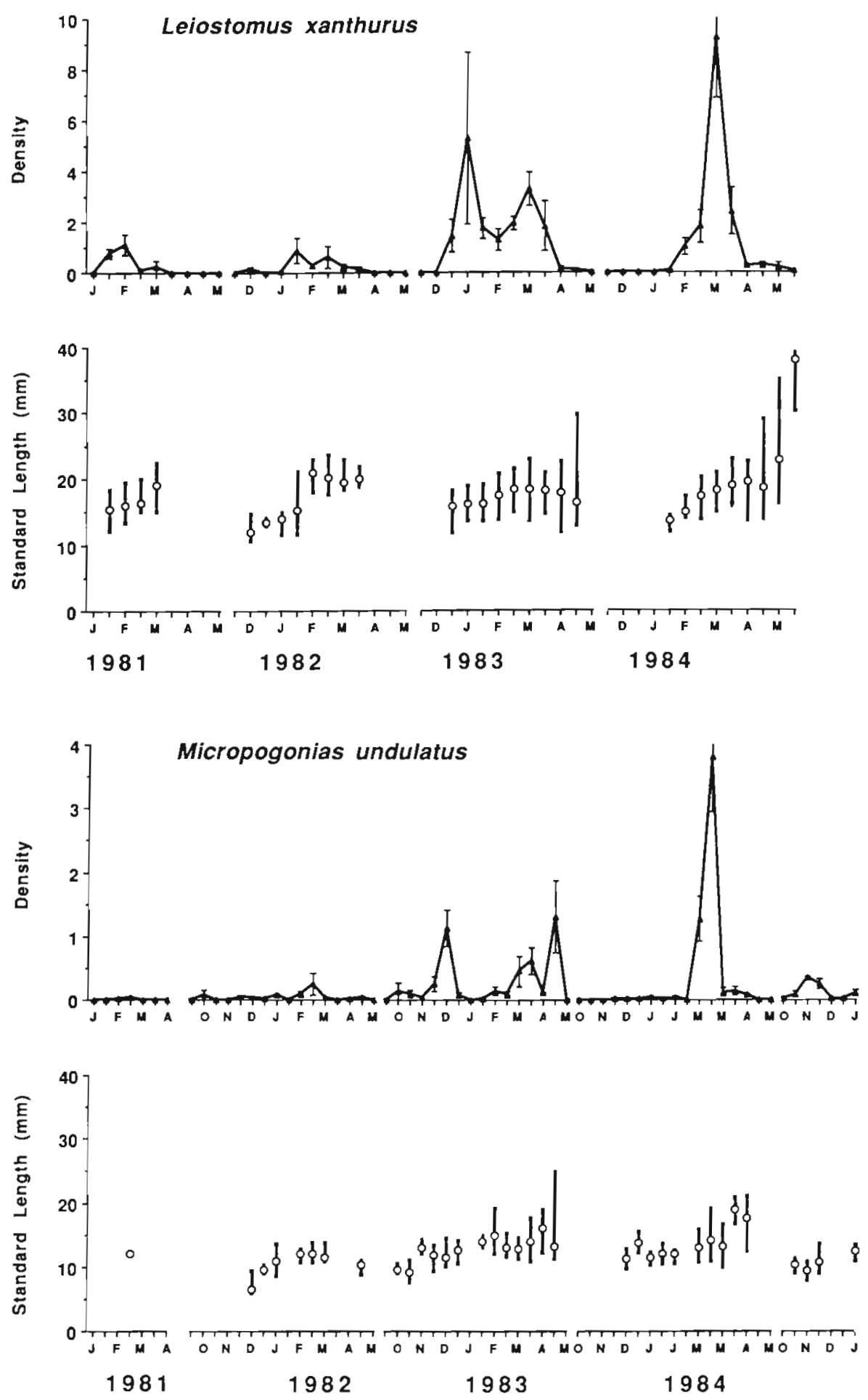

Fig. 5. Leiostomus xanthurus and Micropogonias undulatus. Densities (mean \pm 1 standard error) expressed as number $\mathrm{m}^{-3}$ of spot and Atlantic croaker in biweekly epibenthic sled collections at Stn BB and corresponding length distributions for those dates on which at least 10 individuals were collected. On length distribution plots, open circles indicate median length and solid lines terminate at the minimum and maximum length for that date 
Table 3. Partial results of nested ANOVAs for the 8 most abundant larval fish taxa. Values represent the percent of the total variability accounted for by location (Loc.), year (Yr), cruise date $(\mathrm{Cr}$.), and replication (Rep.)

\begin{tabular}{|lrrrr|}
\hline Taxon & Loc. & Yr & Cr. & Rep. \\
\hline Gobiosoma spp. & 9 & 0 & 87 & 4 \\
Anchoa spp. & 0 & 8 & 76 & 16 \\
Bairdiella chrysoura & 5 & 0 & 67 & 28 \\
Blenniidae & 0 & 1 & 77 & 22 \\
Leiostomus xanthurus & 18 & 8 & 52 & 22 \\
Micropogonias undulatus & 11 & 4 & 66 & 19 \\
Lagodon rhomboides & 4 & 10 & 56 & 30 \\
Myrophis punctatus & 0 & 2 & 87 & 11 \\
\hline
\end{tabular}

than that near the inlet (DD) on 81 of 99 sampling dates. All major taxa were consistently more abundant at BB (Table 4). Patterns of abundance within and among years were similar at BB and DD (Fig. 3), and a significant positive relationship was found between the abundance of total larval fishes at the 2 locations $\left(\mathrm{r}^{2}=\right.$ $0.75, \mathrm{p}<0.01, \mathrm{n}=99$ ). The timing and duration of recruitment periods and the size distributions of larvae of all major taxa were very similar at the creek and inlet site each year.

\section{DISCUSSION}

Seasonal patterns of larval fish recruitment to epibenthic habitats in North Inlet Estuary were very regular Arrival times of major taxa were consistent with reports on the timing of recruitment elsewhere in their geographic ranges (see Hildebrand \& Cable 1930, 1934, 1938, Dahlberg \& Conyers 1973, Chao \& Musick 1977, Powles \& Stender 1978, Colton et al. 1979). In the present study, the seasonal patterns of larval recruitment to subtidal epibenthic habitats were consistent with the results of previous studies in North Inlet Estuary which focused on the utilization of intertidal habitats by winter larvae (Shenker \& Dean 1979. Bozeman \& Dean 1980, Beckman \& Dean 1984) and subtidal areas by juvenile fishes (Ogburn et al. 1988). Even though the timing and duration of larval fish recruitment into North Inlet Estuary was expected to be predictable, such a high degree of regularity was surprising. Only minor interannual variations in arrival times occurred despite water temperatures on dates of first collection differing by as much as $12{ }^{\circ} \mathrm{C}$ among years. Recruitment periods were of similar duration even during years when salinity was significantly lower for weeks or months. Date was the most accurate predicter for the initiation and completion of larval recruitment periods.

Interannual variations in larval fish abundance were typically small with annual means of most taxa differing by a factor of 2 or less. Significant differences were demonstrated between years of lowest and highest abundances, but, for the common taxa, the differences were always less than a factor of 5 . Few multiple year studies of estuarine ichthyoplankton abundance are available for comparison. Able (1978) showed that annual mean densities of one of the most abundant larval fishes (Mallotus villosus) in the St. Lawrence Estuary varied by less than a factor of 2 during a 3 yr study. However, the abundance of other common taxa varied by factors as large as several hundred. In a study of interannual variations in larval anchovy abundances based on 13 yr of data from coastal California, Peterman et al. (1988) demonstrated differences were less than a factor of 6. Hamley et al. (1983) observed 15- to 20 -fold differences in the mean abundance of several

Table 4. Comparisons of abundance among years and between locations for the 8 most abundant larval fish taxa. For Anchoa spp., Leiostomus xanthurus, and Micropogonias undulatus, interaction terms between stations and years in ANOVAs were significant, so Tukey 1 -factor analyses were performed. Years and station-years are listed in order of decreasing abundance, and those not connected by a line are significantly different $(p<0.05)$. DD is the sampling location near the ocean entrance to North Inlet, and $B B$ is the upestuary tidal creek site. Differences between stations were significant $(p<0.05)$

\begin{tabular}{|c|c|c|c|c|c|c|c|c|}
\hline \multicolumn{9}{|l|}{ Summer fishes } \\
\hline Gobiosoma spp. & $\underline{82}$ & 81 & 84 & 83 & & & & $\mathrm{BB}^{*}>\mathrm{DD}$ \\
\hline Anchoa spp. & BB81 & DD81 & DD82 & BB82 & BB83 & BB84 & DD84 DD83 & \\
\hline Bairdiella chrysoura & 82 & 84 & 83 & 81 & & & & $\mathrm{BB} \cdot>\mathrm{DD}$ \\
\hline Blenniidae & $\underline{81}$ & 82 & 84 & 83 & & & & $\mathrm{BB}>\mathrm{DD}$ \\
\hline \multicolumn{9}{|l|}{ Winter fishes } \\
\hline Leiostomus xanthurus & $\underline{B B 83}$ & BB84 & DD83 & $\mathrm{BB} 82$ & DD82 & DD84 & & \\
\hline Micropogonias undulatus & $\underline{B B 84}$ & BB83 & DD83 & $\mathrm{BB} 82$ & DD84 & DD82 & & \\
\hline Lagodon rhomboides & 84 & 83 & 82 & & & & & $\mathrm{BB} \cdot>\mathrm{DD}$ \\
\hline Myrophis punctatus & $\underline{82}$ & 84 & 83 & & & & & $\mathrm{BB} \cdot>\mathrm{DD}$ \\
\hline
\end{tabular}


larval fishes during an 8 yr study in Lake Erie. More information is available on the magnitude of interannual variations of adult than of larval fish abundances, especially in the case of commercially harvested species. Generally, the size of adult fish stocks (i.e. the reproductive potential) does not correspond well to the size of the pool of recruiting larvae (i.e. the reproductive success). Variable survival rates among early life stages of fishes appear to be the most important processes affecting the dynamics of commercially important fish populations (Steele et al. 1980).

The largest year-to-year variations in abundance observed in North Inlet Estuary were for the winter taxa. Significantly higher densities of Atlantic croaker, spot, and pinfish occurred during the winters of 1983 and 1984 when increased freshwater inflow from Winyah Bay depressed salinities in the tidal creeks for several months. It is possible that larger year classes (spawning success and early life stage survival rates) of all 3 dominant winter species occurred in 1983 and 1984 or that wind conditions associated with wet weather patterns affected coastal water mass dynamics in such a way that higher numbers of larvae arrived at local inlets. Once inside the estuary, recruiting postlarvae may have found the low salinity conditions more suitable than the high salinity conditions typical of the tidal creeks of the North Inlet Estuary. This hypothesis is consistent with the results of studies from stratified estuaries in the southeastern USA which have shown that immigrating Atlantic croaker, spot, and pinfish postlarvae move toward freshwater and utilize upper reaches of estuaries as nursery areas; salinity may be the primary factor affecting these recruitment and abundance patterns (Weinstein et al. 1980, Holt \& Strawn 1983, Rogers et al. 1984, Rozas \& Hackney 1984). Since low salinity conditions in North Inlet result. in the increased utilization of the creeks by winter larvae, these epibenthic habitats appear to be habitable but probably not optimal recruitment areas during drier winters.

Although interannual variations in mean densities were less for summer taxa, gobies, anchovies, and blennies were least abundant in 1983 and 1984 following periods of low salinity. Goby and blenny abundances were significantly lower in 1983 than in 1984 , possibly because salinity levels were lower in 1983 ( $<$ $10 \%$ for $1 \mathrm{mo}$ ). Lower densities of gobies, blennies, and other species may have been related to major reductions in amounts of sponges, bryozoans, hydroids, and octocorals collected by the epibenthic sled following wet winters. Changes in the characteristics of these microhabitats may have negatively impacted spawning or the survival or early life stages, especially by resident fish species which utilize these epibenthic areas throughout their life cycles.
Fluctuations in abundance within years accounted for the largest sources of variation for all major taxa. Differences in abundance among sampling dates were typically large and irregular, and did not appear to be related to short-term fluctuations in water temperature or salinity. Some of the largest differences between. consecutive biweekly collections occurred during periods of stable environmental conditions (summer). For each taxon, significantly higher densities usually occurred on 1 or 2 dates each year, but the timing of these peaks was not predictable. However, within years, peak densities of several major taxa often occurred at about the same time. Pulses or waves of larvae originating from distant spawning grounds have been described from many areas (Modde 1980, Frank \& Leggett 1983, Beckman \& Dean 1984, Rogers et al. 1984, Ruple 1984). In many instances, the timing of arrivals at estuarine recruitment areas has been linked to specific hydrographic events (Fortier \& Leggett 1982, de LaFontaine et al. 1984, Norcross \& Shaw 1984). Although patterns of coastal water mass changes outside of North Inlet may have affected recruitment patterns of winter larvae, these processes are probably not useful in explaining the high variability observed for larval fishes produced within the creeks (e.g. gobies, blennies). High initial mortality is typical of larval fishes and variations in survival rates within the first few days following hatching could also contribute to the highly irregular abundance patterns. Large fluctuations in abundance between sampling dates may also be related to spatial and temporal patchiness resulting from uneven reproduction and formation of aggregations of larval fishes (Houde \& Lovdal 1985). Contagious distributions of organisms influence sampling effectiveness and complicate the interpretation of abundance data. In North Inlet, the variability associated with replication within dates was consistently less than that among dates. The patchiness of larvae at the sampling sites did not alone account for the large differences in abundance observed among dates.

Regardless of the sizes or sources of variations in larval abundance, recruitment appeared to be a continuous process within long and well-defined periods. Periodic or synchronous spawnings may have occurred within adult populations, but the presence of small larvae throughout the periods indicated continuous production and arrival. In northern estuaries, where larval recruitment periods are typically short (weeks), a succession of taxa occurs during the warm months. de LaFontaine et al. (1984) speculated that this strategy tends to reduce competition for resources among taxa, thus increasing the likelihood of survival for all constituents. In tropical areas, larval production and recruitment extends over longer periods (months to year round) and there is considerable overlap among 
species (Houde \& Lovdal 1984). Larval fish recruitment periods in North Inlet Estuary appear to be intermediate between these extremes. The simultaneous occurrence of many taxa may not be advantageous to the recruitment success of an individual taxon. Densitydependent survival could explain some of the high variability in abundance among dates that was observed. If short-term inter- or intra-specific competition for food or refugia were high, one would expect continuous recruitment over longer periods to be a compensatory mechanism which would increase the likelihood of survival for some portion of a year class. More research on trophic requirements and competition among larval fishes is necessary to address this hypothesis.

Larval stages of estuarine fishes are often stratified within the water column and many are most abundant near the bottom (Hildebrand \& Cable 1930, Pearcy \& Richards 1962, Able 1978, Weinstein et al. 1980, Jahn \& Lavenberg 1986). Although vertical distributions of larvae probably vary on scales of minutes to months, a review of ichthyoplankton surveys throughout the wide geographic range of the most common North Inlet species suggests some common patterns. In general, larval fish studies based on collections made with epibenthic samplers demonstrate the dominance of gobies (Dokken et al. 1984, Stubblefield et al. 1984, this study) and those which were based on oblique or surface net hauls indicate the prevalence of engraulid and atherinid species (Dovel 1981, Olney 1983, Cowan \& Birdsong 1985, Roper 1986). The dominance of larval Gobiosoma spp. in sled collections from North Inlet Estuary reflects the proximity of the sampling sites to optimal oyster shell spawning habitats (Dahlberg \& Conyers 1973, Crabtree \& Middaugh 1982) and the tendency of presettling larvae to aggregate and swim close to the bottom (Breitburg 1987). If the upper portion of the water column were sampled, we would expect other species, especially anchovies, to comprise larger proportions of the ichthyoplankton of North Inlet Estuary than the results of the epibenthic sled program indicate. Large underestimates of the abundance of several species of flatfishes, serranids, herrings, mullets, and jacks, which first arrive in the estuary at a more advanced and motile stage, probably resulted from the ability of these larvae and postlarvae to avoid the sampling device. Limitations in the effectiveness of collection gear are important to consider in assessing patterns of habitat utilization and in comparing results of different ichthyoplankton studies.

Differences between the creek and inlet sampling sites accounted for a small portion of the total variability within the dataset, but significant differences in abundance were observed for most taxa. Higher abundances at the creek site suggest that areas with a high diversity of microhabitats may have been more favorable to the survival of recruiting larvae. The availability of food resources and refuges from predators may have been higher in this more complex epibenthic habitat. Despite consistently higher densities of both summer and winter taxa at the creek site, the taxonomic composition, size distribution, and relative abundance of species were very similar at the 2 locations. These similarities and the significant positive correlation between the abundance of larval fishes at the 2 sites indicate that the factors influencing intra- and interannual fluctuations in abundance were operating on a larger spatial scale. Ecosystem level changes in environmental conditions appeared to have similar effects on the production, immigration, or survivorship of early life stages of the various taxa comprising the winter and summer assemblages. Other information supporting this conclusion include the small inter-and intraannual variations in rankings and ratios of abundance of major taxa within the seasonal assemblages. However, more frequent sampling will be necessary to elucidate the relationships between patterns of larval fish recruitment and ecosystem parameters.

The degree to which characteristics of recruiting larval fish populations could be predicted from year to year was surprisingly high. These patterns persisted despite interannual fluctuations in winter salinities, which probably represented the maximum extent of such ecosystem level disturbances. Together, these observations suggest that responses of larval fish populations to major changes in the estuarine environment are more strongly expressed as alterations in the magnitude than in the timing of habitat utilization.

Acknowledgements. We especially thank W. K. Michener and D. Edwards, who conducted statistical analyses and assisted with the interpretation of the results. Assistance in field collections was provided by B. McCutchen, T. Swatzel, and P. Kenny. Sample processing assistance was provided by $D$. Chestnut, A. Farlow, M. H. Green, S. Harden, B. Poston, and B. Thomas. We also thank. B. Stender for aid in the identification of larval sciaenids and D. Ruple for help with larval goby taxonomy. K. Caulfield and G. Ogburn are thanked for their roles in the preparation of the manuscript. We also appreciate the many helpful suggestions made by reviewers of earlier drafts. The study was supported by the Ecosystem Study Program of the National Science Foundation through the North Inlet Long-Term Ecological Research Program, Grant DEB 8012165 (F. J. Vermberg, principal investigator).

\section{LITERATURE CITED}

Able, K. W. (1978). Ichthyoplankton of the St. Lawrence Estuary: composition, distribution, and abundance. J. Fish. Res. Bd Can. 35: 1518-1531

Beckley, L. E. (1986). The ichthyoplankton assemblage of the Algoa Bay nearshore region in relation to coastal zone utilization by juvenile fish. S. Afr. J. Zool. 21: 244-252 
Beckmann, D. W., Dean, J. M. (1984). The age and growth of young-of-the-year spot, Leiostomus xanthurus Lacepede in South Carolina. Estuaries 7: 487-496

Bourne, D. W., Govoni, J. J. (1988). Distribution of fish eggs and larvae and patterns of water circulation in Narragansett Bay, 1972-1973. Am. Fish. Soc. Symp. 3: 132-148

Bozeman, E. L. Jr, Dean, J. M. (1980). The abundance of estuarine larval and juvenile fish in a South Carolina intertidal creek. Estuaries 3: 89-97

Breitburg, D. (1987). Larval schooling behavior of a nonschooling benthic fish species. EOS (Trans. Am. Geophys. Un.) 68: 1750

Bye, V. J. (1984). The role of environmental factors in the timing of reproductive cycles. In: Potts, G. W., Wooten, R. J. (eds.) Fish reproduction: strategy and tactics. Academic Press, London, p. 187-205

Cain, R. L., Dean, J. M. (1976). Annual occurrence, abundance and diversity of fish in a South Carolina intertidal creek. Mar. Biol. 36: 369-379

Carr, W E. S., Adams, C. A. (1973). Food habits of juvenile marine fishes occupying seagrass beds in the estuarine zone near Crystal River, Florida. Trans. Am. Fish. Soc. 102: 511-540

Chao, L. N., Musick, J. A. (1977). Life history, feeding habits, and functional morphology of juvenile sciaenid fishes in the York River Estuary, Virginia. Fish. Bull. U.S. 75: $657-702$

Colton, J. B. Jr, Smith, W. G., Kendall, A. W. Jr, Berrien, P. L. Fahay, M. P. (1979). Principal spawning areas and times of marine fishes, Cape Sable to Cape Hatteras. Fish. Bull. U.S. 76: 911-915

Cowan, J. H. Jr, Birdsong, R. S. (1985). Seasonal occurrence of larval and juvenile fishes in a Virginia Atlantic Coast estuary with emphasis on drums (Family Sciaenidae). Estuaries 8: 48-59

Crabtree, R. E., Middaugh, D. P. (1982). Oyster shell size and the selection of spawning sites by Chasmodes bosquianus, Hypleurochilus geminatus, Hypsoblennius ionthas (Pisces, Blenniidae), and Gobjosoma bosci (Pisces, Gobiidae). Estuaries 5: 150-155

Croker, R. A. (1965). Planktonic fish eggs and larvae of Sandy Hook Estuary. Chesapeake Sci. 6: 92-95

Cushing, D. H. (1975). Marine ecology and fisheries. Cambridge University Press, Cambridge

Dahlberg, M. D., Conyers, J. C. (1973). An ecological study of Gobiosoma bosci and G. ginsburgi (Pisces, Gobiidae) on the Georgia coast. Fish. Bull. U.S. 71. 279-287

de LaFontaine, Y., Sinclair, M., El-Sabh, M. I., Lassus, C., Fournier, R. (1984). Temporal occurrence of ichthyoplankton in relation to hydrographic and biological variables at a fixed station in the St. Lawrence Estuary. Estuar. coast. Shelf Sci. 18: 177-190

Dokken, Q. R., Matlock, G. C., Cornelius, S. (1984). Distribution and composition of larval fish populations with Alazan Bay, Texas. Cont. mar. Sci. 27. 205-222

Dovel, W. L. (1981). Ichthyoplankton of the lower Hudson Estuary, New York, N. Y Fish. Game. J. 28: 21-39

Fortier, L. Leggett, W. C. (1982). Fickian transport and the dispersal of fish larvae in estuaries. Can. J. Fish. Aquat Sci. 39: 1150-1163

Frank, K. T., Leggett, W C. (1983). Multispecies larval fish associations: accident or adaptation? Can. J. Fish. Aquat. Sci. $40: 754-762$

Hamley, J. M. Howley, T P., Punhani, A. L. (1983). Estimating larval fish abundances from plankton net catches in Long Point Bay, Lake Erie, in 1971-1978. J. Great Lakes Res. 9: $452-467$
Herke, W. H. (1971). Use of natural, and semi-impounded, Louisiana tidal marshes as nurseries for fishes and crustaceans. Ph. D thesis Louisiana State Univ., Baton Rouge

Herman. S. S. (1963). Planktonic fish eggs and larvae of Narraganssett Bay. Limnol. Oceanogr. 8: 103-109

Hildebrand, S. F. Cable, L. E. (1930). Development and life history of fourteen teleostean fishes at Beaufort, N. C. Bull. U.S. Bur. Fish. 46: 383-488

Hildebrand, S. F., Cable, L. E. (1934). Reproduction and development of whitings or kingfishes, drums, spot, croaker, and weakfishes or sea trouts, Family Sciaenidae of the Atlantic Coast of the United States. Fish. Bull. U.S. 48: 41-117

Hildebrand, S. F, Cable, L. E. (1938). Further notes on the development and life history of some teleosts at Beaufort, N. C. Fish Bull. U.S. 48: 506-642

Holt, J., Strawn, K. (1983). Community structure of macrozooplankton in Trinity and Upper Galveston Bays, Texas. Estuaries 6: 66-75

Houde, E. D., Lovdal, J. D. A. (1984). Seasonality of occurrence, foods, and food preferences of ichthyoplankton in Biscayne Bay, Florida. Estuar. coast. Shelf. Sci. 18: 403-419

Houde, E. D., Lovdal, J. D. A. (1985). Patterns of variability in ichthyoplankton occurrence and abundance in Biscayne Bay, Florida. Estuar. coast. Shelf Sci. 20: 79-103

Jahn, A. E., Lavenberg, R. J. (1986). Fine-scale distribution of nearshore, suprabenthic fish larvae. Mar. Ecol. Prog. Ser. 31: 223-231

Jenkins, G. P. (1986). Composition, seasonality, and distribution of ichthyoplankton in Port Phillip Bay, Victoria. Aust J. mar. Freshwat. Res. 37: 507-520

Kjerfve, B., Proehl, J. A., Schwing, F. B., Seim, H. E., Marozas, M. (1982). Temporal and spatial considerations in measuring estuarine water fluxes. In: Kennedy, $V$ S. (ed.). Estuarine comparisons. Academic Press, New York, p. $37-51$

Kneib, R. T (1984). Patterns in the utilization of the intertidal salt marsh by larvae and juveniles of Fundulus heteroclitus (Linnaeus) and Fundulus luciae (Baird). J. exp. mar Biol. Ecol. 83: 41-51

McHugh, J. L. (1967). Estuarine nekton, In: Lauff, G. H. (ed.) Estuaries. Am. Assoc. Adv. Sci. Publ. 83, Washington D.C., p. $581-620$

Mize, C. W., Schultz, R. C. (1985). Comparing treatment means correctly and appropriately. Can. J. For. Res. 15: $1142-1148$

Modde, T. (1980). Growth and residency of juvenile fishes within a surf zone habitat in the Gulf of Mexico. Gulf Res. Rep. 6: $377-385$

Modde, T., Ross, S. T. (1981). Seasonality of fishes occupying a surf zone habitat in the northern Gulf of Mexico. Fish. Bull. U.S. 78: 911-921

Norcross, B. L., Shaw, R. F. (1984). Oceanic and estuarine transport of fish eggs and larvae. A review. Trans. Am. Fish. Soc. 113: 153-165

Ogburn, M. O., Allen, D. M., Michener, W. K. (1988). Fishes shrimps. and crabs of the North Inlet Estuary. S.C.: a fouryear seine and trawl survey. Baruch Institute Tech. Rpt 88-1. Univ. of South Carolina, Columbia

Olney, J. E. (1983). Eggs and early larvae of the bay anchovy Anchoa mitchilli, and the weakfish, Cynoscion regalis, in lower Chesapeake Bay with notes on associated ichthyoplankton. Estuaries 6: 20-35

Olney, J. E.. Boehlert, G. W. (1988). Nearshore ichthyoplankton associated with seagrass beds in the lower Chesapeake Bay. Mar Ecol. Prog. Ser. 45: 33-43

Pearcy, W. G., Richards, S. W. (1962). Distribution and ecology 
of fishes of the Mystic River Estuary, Connecticut. Ecology 43: 248-259

Peterman, R. M., Bradford, M. J., Lo, N. C. H., Methot, R.D. (1988). Contribution of early life stages to interannual variability in recruitment of northern anchovy (Engraulis mordax). J. Fish. Res. Bd Can. 45: 8-16

Powles, H., Stender, B. W. (1978). Taxonomic data on the early life history stages of Sciaenidae of the South Atlantic Bight of the United States. Tech. Rep. S.C. Mar. Res. Cent. 31: 1-64

Rogers, S. G., Targett, T E., Van Sant, S. B. (1984). Fishnursery use in Georgia salt-marsh estuaries: the influence of spring-time freshwater conditions. Trans. Am. Fish. Soc. 113: 595-606

Roper, D. S. (1986). Occurrence and recruitment of fish larvae in a northern New Zealand estuary. Estuar coast. Shelf Sci. 22: 705-717

Royce, W. F. (1972). Introduction to the fishery sciences. Academic Press, New York

Rozas, L. P., Hackney, C. T. (1984). Use of oligohaline marshes by fishes and macrofaunal crustaceans in North Carolina. Estuaries 7: 213-224

Ruple, D. L. (1984). Occurrence of larval fishes in the surf zone of a northern Gulf of Mexico Barrier Island. Estuar. coast. Shelf Sci. 18: 191-208

SAS Institute, Inc. (1982). SAS users guide. SAS Institute, Inc., Carey, North Carolina

Shenker, J. M., Dean, J. M. (1979). The utilization of an intertidal salt marsh creek by larval and juvenile fishes. Abundance, diversity and temporal variation. Estuaries 2: 154-163

This article was submitted to the editor
Sherman, K, Smith, W., Morse, W., Berman, M., Green, J., Ejsymont, L. (1984). Spawning strategies of fishes in relation to circulation, phytoplankton production, and pulses in zooplankton off the northeastern United States. Mar Ecol. Prog. Ser. 18: 1-19

Sokal, R. R., Rohlf, F. J. (1981). Biometry, 2nd edn. W. H. Freeman and Co., San Francisco

Steele, J, Clark, C., Larkin, P., Lasker, R., May, R., Rothschild, B., Ursin, E., Waish, J., Wooster, W. (1980). Fisheries ecology: some constraints that impede our understanding Ocean Science Board, National Academy of Science, Washington

Stubblefield, C. L., Lascara, C. M., Vecchione, M. (1984). Vertical distribution of zooplankton in a shallow turbid estuary. Contr. mar. Sci. Univ. Tex. 27: 93-104

Talbot, C. W., Able, K. W. (1984). Composition and distribution of larval fishes in New Jersey high marshes. Estuaries 7: $434-443$

Weinstein, M. P. (1979). Shallow marsh habitats as primary nurseries for fishes and shellfish, Cape Fear River, North Carolina. Fish. Bull. U.S. 77: 339-357

Weinstein, M. P., Weiss, S. L., Hodson, R. G., Gerry, L. R. (1980). Retention of three taxa of postlarval fishes in an intensively flushed tidal estuary, Cape Fear River, North Carolina. Fish. Bull. U.S. 78: 419-436

Zijlstra, J. J. (1972). On the importance of the Waddensea as a nursery area in relation to the conservation of the southern North Sea fishery resources. Symp. Zool. Soc. Lond. 29 233-258

Manuscript first received: March 20,1989

Revised version accepted: February 28, 1990 